\title{
Characterization of canine coronavirus spread among domestic dogs in Vietnam
}

\author{
Dung van NGUYEN ${ }^{1)}$, Yukata TERADA ${ }^{1)}$, Shohei MINAMI ${ }^{1)}$, Kenzo YONEMITSU ${ }^{1)}$, \\ Nao NAGATA ${ }^{1)}$, Thanh Dinh Ha LE $^{2)}$, Ryusei KUWATA ${ }^{1)}$, Hiroshi SHIMODA ${ }^{1)}$ and \\ Ken MAEDA ${ }^{1)^{*}}$ \\ 1)Laboratory of Veterinary Microbiology, Joint Faculty of Veterinary Medicine, Yamaguchi University, 1677-1 \\ Yoshida, Yamaguchi 753-8515, Japan \\ ${ }^{2)}$ Veterinary Diagnostic Laboratory, Sub-Department of Animal Health of Ho Chi Minh City, 151 Ly Thuong Kiet, \\ District 11, Ho Chi Minh City, Vietnam
}

J. Vet. Med. Sci.

79(2): 343-349, 2017

doi: 10.1292/jvms.16-0538

Received: 17 October 2016 Accepted: 1 November 2016 Published online in J-STAGE:

14 November 2016

\begin{abstract}
Canine coronavirus (CCoV) is an important pathogen that causes enteritis in dogs, but there is no information on CCoV infection in Vietnam. To examine the prevalence of CCoV infection among Vietnamese dogs, 201 serum samples were analyzed by virus-neutralization (VN) test. The results showed that antibody against CCoV-II was present in 87 dogs (43.3\%). To detect genes of CCoV, fecal samples collected from 30 diarrheic and 50 healthy dogs were examinated by RT-PCR, confirming that 2 diarrheic dogs and 5 healthy dogs were positive for CCoV. Nucleotide sequences of $N$-terminal region of spike (S) gene indicated that CCoV strains were divided into two subgenotypes, CCoV-Ila and -IIb, respectively. Furthemore, we succeeded in isolating CCoV/ $\mathrm{dog} / \mathrm{HCM} 47 / 2015$, the isolate was plaque-purified three times, and 3'-terminal one-third of the genome was analyzed. Interestingly, the plaque-purified virus had a large deletion in ORF3abc and E genes $(1,165 \mathrm{nt})$, and a short deletion in ORF7b gene (60 nt), suggesting that these regions are not necessary for in vitro replication of CCoV. Next, the antigenicity between the isolated CCoV-IIb and the other CCoV-Ila was compared by VN test, revealing that antigenicty of the isolated CCoV is equal or higher than that of the other CCoV. In summary, two subgenotypes of CCoV-II are spreading among Vietnamese dogs. The isolated virus with a large deletion after in vitro passage may be useful for the development of vaccine, owing to its antigenicity and efficient viral growth in vitro.
\end{abstract}

KEY WORDS: coronavirus, dog, genotype

Canine coronavirus (CCoV) was first recognized in an outbreak of gastroenteritis among dogs in 1971 [4]. Since then, CCoV infection has been reported in dogs in many countries $[5,7,9,12,17,25,28,29,32]$. To date, however, information on $\mathrm{CCoV}$ in Vietnam has been unavailable.

$\mathrm{CCoV}$ is a single-stranded, positive-sense RNA virus that belongs to the genus Alphacoronavirus. CCoV was divided into two genotypes, $\mathrm{CCoV}$ type I (CCoV-I) and CCoV type II (CCoV-II), which can be differentiated by nucleotide sequences of the spike (S) gene and the presence of ORF3 located downstream of the $\mathrm{S}$ gene $[6,22]$. CCoV-II is also divided into two subgenotypes, $\mathrm{CCoV}$-IIa and CCoV-IIb, based on the amino acid sequence of the $N$-terminal region of the $\mathrm{S}$ protein. In the $N$-terminal region of the $\mathrm{S}$ protein of CCoV-IIb, the amino acid sequences are highly similar to those of transmissible gastroenteritis viruses (TGEV) $[14,16,23]$.

In this study, the prevalence of CCoV infection among domestic dogs in Vietnam was examined, and Vietnamese CCoVs were genetically and antigenically characterized.

\section{MATERIALS AND METHODS}

\section{Fecal swabs}

A total of 80 fecal swabs were collected from 30 diarrheic and 50 healthy dogs in animal hospitals and households, respectively, in Ho Chi Minh City in Vietnam from 2013 to 2015. Their ages ranged from 2 months to 13 years. Swab samples were dissolved in $2 \mathrm{ml}$ of phosphate-buffer saline (PBS), filtrated through a $0.22-\mu \mathrm{m}$ filter (Millipore, Carrigtwohill, Ireland) and stored at $-80^{\circ} \mathrm{C}$ until analysis.

*Correspondence to: Maeda, K., Laboratory of Veterinary Microbiology, Joint Faculty of Veterinary Medicine, Yamaguchi University, 1677-1 Yoshida, Yamaguchi 753-8515, Japan. e-mail: kmaeda@yamaguchi-u.ac.jp

(C2017 The Japanese Society of Veterinary Science

This is an open-access article distributed under the terms of the Creative Commons Attribution Non-Commercial No Derivatives (by-ncnd) License <http://creativecommons.org/licenses/by-nc-nd/4.0/>. 
Sera

A total of 201 serum samples were collected from healthy dogs in different districts in Ho Chi Minh City from 2013 to 2015 and stored at $-20^{\circ} \mathrm{C}$ until analysis.

\section{Viral RNA extraction}

RNA was extracted from CCoV-infected cells and filtrated fecal swabs using RNeasy Mini kit (Qiagen, Hilden, Germany) and Viral RNA Mini Kit (Qiagen), respectively.

\section{Reverse transciption-polymerase chain reaction (RT-PCR)}

RT-PCR was performed using QIAGEN One step RT-PCR (Qiagen). The primer sets ORF3F, 5'-CAC TAA ACT CAA AAT GTT GAT TC-3' and ORF3R, 5'-TTA AGG ATT AAA AAC ATA TTC TA-3' [15] and 2bF, 5'-AGG TTG TTG TGG ATG CAT AG-3' and 2bR, 5'-ACG GTC AAG TTC GTC AAG TA-3' [3], were used for detection of CCoV-I and CCoV-II, respectively. Amplified products were confirmed as $628 \mathrm{bp}$ for CCoV-I and $232 \mathrm{bp}$ for CCoV-II by electrophoresis on 2\% agarose gels and were then purified using QIAquick PCR Purification kits (Qiagen) for sequencing.

For differentiation of CCoV subgenotypes, primers 1bF, 5'-TTG ATT CAA AGA TTT GAG TAT TGG-3' and CCVSR, 5'-GTT AGT TTG TCT AAT AAT ACC AAC ACC-3', were used to amplify the 5'-terminal region of the S gene [30]. RT-PCR was performed using a TaKaRa RNA LA PCR ${ }^{\text {TM }}$ kit (AMV) Ver.1.1 (Takara, Otsu, Japan). RT was carried out with random 9-mer primers at $30^{\circ} \mathrm{C}$ for $10 \mathrm{~min}, 42^{\circ} \mathrm{C}$ for $30 \mathrm{~min}$ and $99^{\circ} \mathrm{C}$ for $5 \mathrm{~min}$, and then, PCR was performed. Amplified fragments were purified using a QIAquick PCR Purification kit (Qiagen) for sequencing.

\section{Virus isolation}

Felis catus whole fetus-4 cells (fcwf-4 cells; ATCC Number: CRL-2787) [11] were maintained in Dulbecco's minimum essential medium (DMEM; Life Technologies, St. Louis, MO, U.S.A.) containing 10\% heat-inactivated fetal calf serum (FCS; Sigma-Aldrich), $100 \mathrm{units} / \mathrm{m} l$ penicillin and $100 \mu \mathrm{g} / \mathrm{m} l$ streptomycin (Life Technologies). Fcwf-4 cells in 6-well plates were inoculated with extracts from $\mathrm{CCoV}$-positive feces and were then incubated at $37^{\circ} \mathrm{C}$ in a $5 \% \mathrm{CO}_{2}$ incubator. Cells were observed daily for cytopathic effects (CPE). If there were no CPE, cells were blind-passaged five times.

\section{Plaque-purification}

Isolated CCoV was plaque-purified three times. Briefly, 10 PFU of CCoV were inoculated on fcwf-4 cells in 6-well plates. After $1 \mathrm{hr}$ of adsorption, inoculum was removed, and 0.8\% agarose in DMEM containing 10\% FCS was overlaid on cells. After the appearance of CPE, plaques were picked up by tips and dissolved into DMEM. This plaque-purification procedure was repeated three times.

\section{Nucleotide sequence analysis}

The sequence of the 3'-terminal one-third of the viral genome from S gene to poly A was determined by RT-PCR using TaKaRa RNA LA PCR ${ }^{\mathrm{TM}}$ kit (AMV) Ver.1.1 (Takara). RT was carried out with random 9-mer primers at $30^{\circ} \mathrm{C}$ for 10 min, $42^{\circ} \mathrm{C}$ for 30 min, $99^{\circ} \mathrm{C}$ for $5 \mathrm{~min}$ and $4^{\circ} \mathrm{C}$ or oligo dT-Adaptor primer at $42^{\circ} \mathrm{C}$ for $30 \mathrm{~min}, 99^{\circ} \mathrm{C}$ for $5 \mathrm{~min}$ and $4^{\circ} \mathrm{C}$ for 5 min. Then, PCR was performed with the following primers: 1bF, 5'-TTG ATT CAA AGA TTT GAG TAT TGG-3'; CCVSR, 5'-GTT AGT TTG TCT AAT AAT ACC AAC ACC-3'; CCVScenF, 5'-TAA GTA ACA TCA CAC TAC C-3'; S6, 5'-CCA AGG CCA TTT TAC ATA AG-3'; ScenFF3, 5'-CTG GAC TGT ACC TGA ATT G-3'; and the reverse primer M13 primer M4, 5'-GTT TTC CCA GTC ACG AC-3'. In order to amplify the S gene of CCoV-IIa, PCR was performed using the following pimers: $1 \mathrm{bF}, \mathrm{CCVSR}, \mathrm{CCVS} 2 \mathrm{CenF}$, 5'- CTA TTC TGT GAC ACC ATG TG-3' [30] and 2bR. Amplified products were confirmed by electrophoresis on $0.8 \%$ agarose gels and were then purified using the QIAquick PCR Purification kit (Qiagen). The nucleotide sequences were determined by an ABI PRISM 310 Genetic Analyzer auto sequencer (Applied Biosystems, Carlsbad, CA, U.S.A.). Sequences were assembled and analyzed using GENETYX ${ }^{\circledR}$ ver.8 (Software Development Co., Tokyo, Japan).

\section{Virus-neutralizing (VN) test}

VN testing was performed using fcwf-4 cells as described previously [26, 30] with modifications. CCoV-IIa fc1, isolated in Japan in 1990 [1], and CCoV-IIb CCoV/dog/HCM47/2015 strain, which was isolated and plaque-purified three times in this study, were used. Briefly, dog sera were inactivated at $56^{\circ} \mathrm{C}$ for $30 \mathrm{~min}$ before $\mathrm{VN}$ test. Equal volumes of two-fold serially diluted sera and virus solution containing $2.0 \times 10^{3} \mathrm{PFU} / \mathrm{m} l$ of $\mathrm{CCoV}$ were mixed and incubated at $37^{\circ} \mathrm{C}$ for $1 \mathrm{hr}$. Then, $50 \mu l$ of this mixture was inoculated onto fcwf- 4 cells monolayer in 24 -well plates. After adsorption at $37^{\circ} \mathrm{C}$ for $1 \mathrm{hr}$, inoculum was removed, and $0.8 \%$ agarose (Lonza, Rockland, ME, U.S.A.) in DMEM containing $10 \%$ FCS was overlaid. Infected cells were incubated at $37^{\circ} \mathrm{C}$ until CPE was observed, followed by fixing with phosphate-buffered formalin and staining with crystal violet. When the number of plaques was less than $75 \%$ of those in control wells, diluted sera were judged to be positive. Titers were expressed as the highest serum dilution showing $75 \%$ plaque reduction or more.

\section{Phylogenetic analysis}

Phylogenetic relationships based on the nucleotide sequences of the $5^{\prime}$-terminal region of $\mathrm{S}$ genes or complete $\mathrm{S}$ genes were analyzed using distance-based (neighbor-joining) with MEGA 7.0 software [13]. Bootstrap values were calculated based on 1,000 replicates. 
Table 1. Prevalence of anti-CCoV-II antibody among 201 domestic dogs in Ho Chi Minh City, Vietnam

\begin{tabular}{llrrc}
\hline & & No. of examined dogs & No. of positive dogs & Ratio of positive dogs (\%) \\
\hline \multirow{2}{*}{ Sex } & Female & 101 & 45 & 44.6 \\
& Male & 100 & 42 & 42.0 \\
\hline \multirow{4}{*}{ Age } & $<1$ & 28 & 8 & $28.6^{\mathrm{a}}$ \\
& 1 & 44 & 14 & 31.8 \\
& 2 & 54 & 26 & 48.1 \\
& $\geq 3$ & 75 & 39 & $52.0^{\mathrm{a}}$ \\
\hline \multirow{3}{*}{ Breed } & Vietnamese & 120 & 47 & $\left.39.2^{\mathrm{b}}\right)$ \\
& Mixed & 51 & 21 & 41.2 \\
& Other & 30 & 19 & $63.3^{\mathrm{b}}$ \\
\hline
\end{tabular}

a, b) Significant difference $(P<0.05)$.

\section{Statistical analysis}

Chi-squared and Fisher's exact probability tests were used for statistical analysis. $P$ values of $<0.05$ were considered to be statistically significant.

\section{RESULTS}

\section{Prevalence of antibody against CCoV-II in dogs in Ho Chi Minh}

Eighty-seven dogs $(43.3 \%)$ were positive for anti-CCoV-II antibody. Prevalence of anti-CCoV-II antibody in dogs aged over 3 years $(52.0 \%)$ was significantly higher than that in dogs aged under 1 year $(28.6 \%)(P<0.05)$. Prevalence of anti-CCoV-II antibody in Vietnamese (39.2\%) was significantly lower than that in other breeds (63.3\%) (Table 1). Antibody titer against CCoV-II ranged from 1:10 to $1: 320$ (data not shown).

\section{Detection of $\mathrm{CCoV}$ in diarrheic and healthy dogs}

To detect CCoV-I and CCoV-II genes in fecal samples, RT-PCR was carried out using fecal samples from 30 diarrheic and 50 healthy dogs. Although CCoV-I was not detected, CCoV-II was detected from two diarrheic dogs (6.7\%) and five healthy dogs $(10 \%, 5 / 50)$ (Table S1). Next, nucleotide sequences of 5'-terminal region of the S gene were analyzed to differentiate subgenotypes of CCoV-II and were deposited into the DNA database of Japan (DDBJ; Accession No. LC190901-LC190907) (Table S1). Phylogenetic analysis based on the 5'-terminal region of the $\mathrm{S}$ gene showed that one and six strains belonged to CCoV-IIa and CCoV-IIb, respectively (Fig. 1 and Table S1). Vietnamese CCoVs-IIb formed one cluster and was similar to Chinese ferret badger DM95/2003 (95.4-95.6\%) and CCoV/NTU336/F/2008 (95.2-95.6\%). Vietnamese CCoV-IIa was similar to Raccoon dog GZ43/2003 (95.6\%) (Fig. 1).

\section{Phylogenetic analysis based on $S$ genes}

Next, the full length of the S gene of CCoV/dog/HCM27/2014 was also determined (4,362 nt, DDBJ Accession No. LC190906). Phylogenetic analysis based on complete S genes showed that Vietnamese CCoV/HCM47/2015 was similar to Chinese ferret badger CoV/DM95/2003 (95.9\%) and CCoV/NTU336/F/2008 (95.2\%), and that Vietnamese CCoV-IIa, CCoV/dog/HCM27/2014 was similar to Raccoon dog CoV/GZ43/2003 (97.4\%) (Fig. 2).

\section{Virus isolation and large deletion in plaque-purified $\mathrm{CCoV}$}

One CCoV-IIb was successfully isolated from a healthy dog (female, six years old) and designated as CCoV/dog/HCM47/2015. For further analysis, the isolate was plaque-purified three times, and the nucleotide sequence of the 3 '-terminal one-third $\mathrm{CCoV}$ genome from the S gene to poly A $(8,995 \mathrm{nt})$ was determined. Surprisingly, the plaque-purified CCoV had a large deletion in the ORF3abc and partial E genes (1,165 nt), and a short deletion in the ORF7b gene (60 nt). Next, we determined nucleotide sequences of the original virus in the feces, confirming that the original virus in feces did not have any deletions (DDBJ Accession No. LC190907) (Fig. 3).

\section{Comparison of antinenicity between CcoV-IIa and -IIb}

To compare antibody titers against CCoV-IIa and -IIb, 60 sera were examined by VN testing using fc1 and plaque-purified $\mathrm{CCoV} / \mathrm{dog} / \mathrm{HCM} 47 / 2015$, respectively. The results showed that positivity of antibody against CCoV-IIb (58.3\%) was slightly higher than that against CCoV-IIa (51.7\%) (Table 2). Four additional dogs became positive for anti-CCoV-IIb antibody, and nine dogs had significantly higher antibody titers (over 4-fold) against CCoV-IIb than CCoV-IIa (data not shown). 


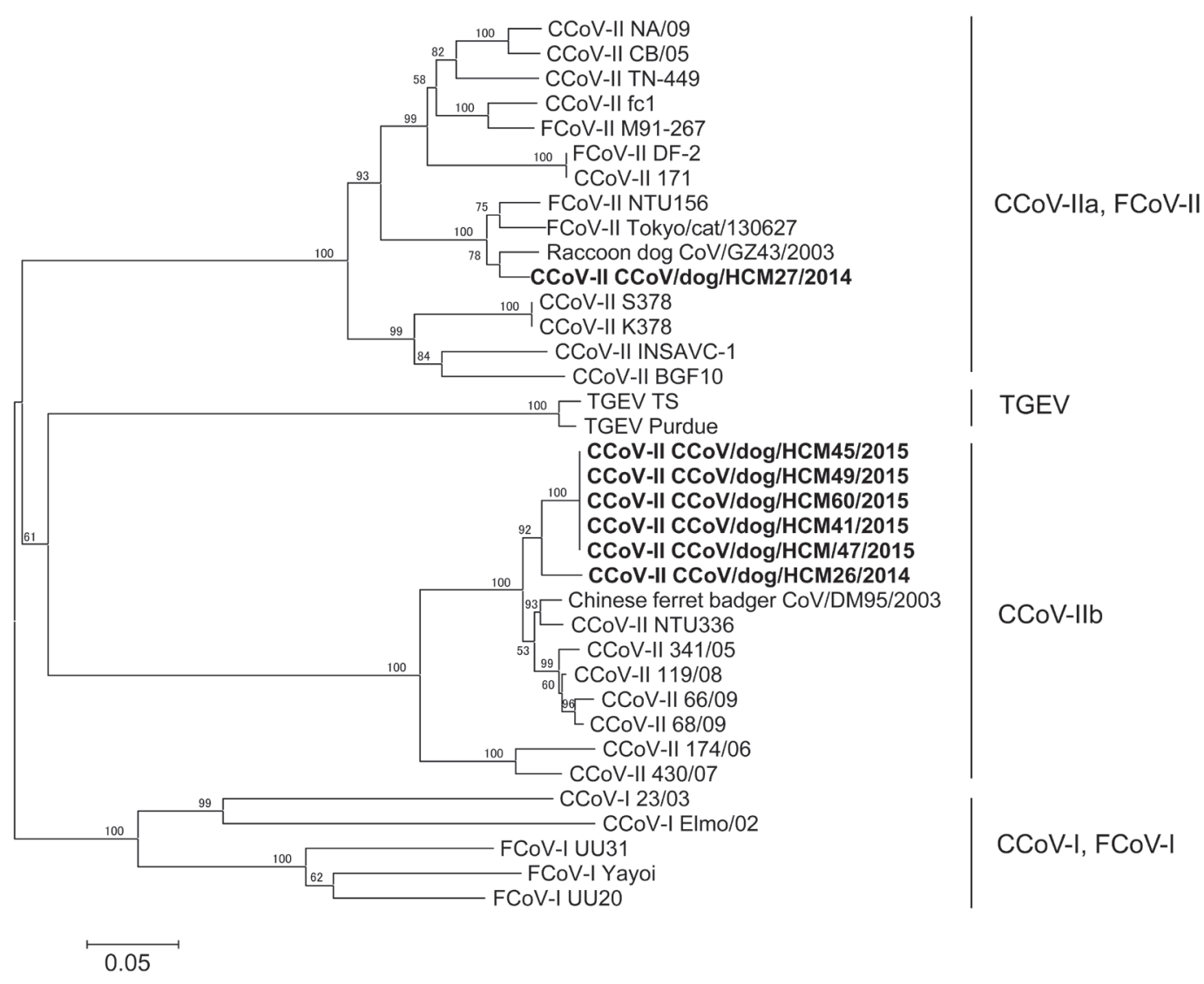

Fig. 1. Phylogenetic analysis based on 5'-terminal region of spike genes (476 nt). Vietnamese CCoVs in feces collected from diarrheic and healthy dogs are shown in bold. GeneBank accession numbers of reference strains are as follows: CCoV-II: SK378 (KC175341), K378 (KC175340), Insavc-1 (D13096.1), BGF10 (AY342160.1), NA/09 (JF682842.1), CB/05 (KP981644.1), fc1 (AB781790), TN449 (JQ404410), 171 (KC175339), Chinese ferret CoV/DM95/2003 (EF192156.1), NTU-336 (GQ477367), 430/07 (EU924790), 174/06 (EU856362), 341/05 (EU856361.1), 66/09 (HQ450376), 68/09 (HQ450377.1), 119/08 (EU924791.1) and Raccoon dog CoV/GZ43/2003 (EF192155). FCoV-I: UU20 (HQ392471.1), UU31 (HQ012371.1) and Yayoi (AB695067.1); FCoV-II: NTU156 (GQ152141.1), DF-2 (DQ286398.1), M91-267 (AB781788.1) and Tokyo/cat/130627 (AB907624.1). CCoV-I: 23/03 (KP84972.1) and Elmo/02 (AY307020.1); TGEV: Purdue (DQ811789.2) and TS (DQ201447).

\section{DISCUSSION}

In this study, the prevalence of anti-CCoV-II anibody was $43.3 \%$, suggesting that CCoV-II has been spreading among the dog population in Ho Chi Minh, Vietnam. Seroprevalance of CCoV infection was $15.8 \%$ in the open population and $40.8 \%$ in kenneled populations in Australia, 44.1\% in Japan, $90.8 \%$ in Italy and 96.5\% in Turkey [1, 9, 19, 24]. Sera from dogs in Vietnam reacted more strongly with CCoV-IIb than CCoV-IIa (Table 2), indicating that CCoV-IIb is the major genotype in Vietnam. The results of RT-PCR in this study also supported the notion that CCoV-IIb is the predominant genotype circulating in domestic dogs in Vietnam (Fig.1, Table S1).

The prevalance of antibody against CCoV-II increased with age (Table 1). Similar results were reported in Turkey [9]. Older dogs must have more opportunities to be infected with CCoV. Seroprevalence of CCoV-II in imported breeds (63.3\%) was significantly higher than that in domestic breeds (39.2\%). There have been similar reports in Japan [27, 29], indicating that many dogs are infected with $\mathrm{CCoV}$ while housed with breeders or in pet shops.

In this study, two diarrheic dogs $(6.7 \%)$ and five healthy dogs $(10 \%)$ were positive for CCoV-II, but no dogs were positive for $\mathrm{CCoV}$-I. One of seven Vietnamese CCoVs strains was positive for CCoV-IIa, and others were positive for CCoV-IIb. Positivity for CCoV-I and CCoV-II in feces of dogs has been reported in Japan (CCoV-I: 53.2\% and CCoV-II: 56.9\%) [28], China (CCoV-I: 4.5\% and CCoV-II: 23.9\%) [32], Italy (CCoV-I: 25.2\% and CCoV-II: 36.3\%), United Kingdom (CCoV-I: $15.0 \%$ and CCoV-II: 20.6\%), Hungary (CCoV-I: 22\% and CCoV-II: 15\%), Greece (CCoV-I: 37\% and CCoV-II: 36\%) [7], Brazil (CCoV-I: 47\% and CCoV-II: 63\%) [5] and Korea (CCoV-I: 22\% and CCoV-II: 10\%) [12]. In Vietnam, CCoV-II, especially CCoV-IIb, may be more predominant among the dog population than CCoV-I. However, CCoV-I infection in Vietnamese dogs should be examined by RT-PCR using further primer sets specific for CCoV-I.

Both CCoV-IIa and IIb cause enteritis, and the lesion is limited to the small intestine [17]. On the other hand, pantropic 


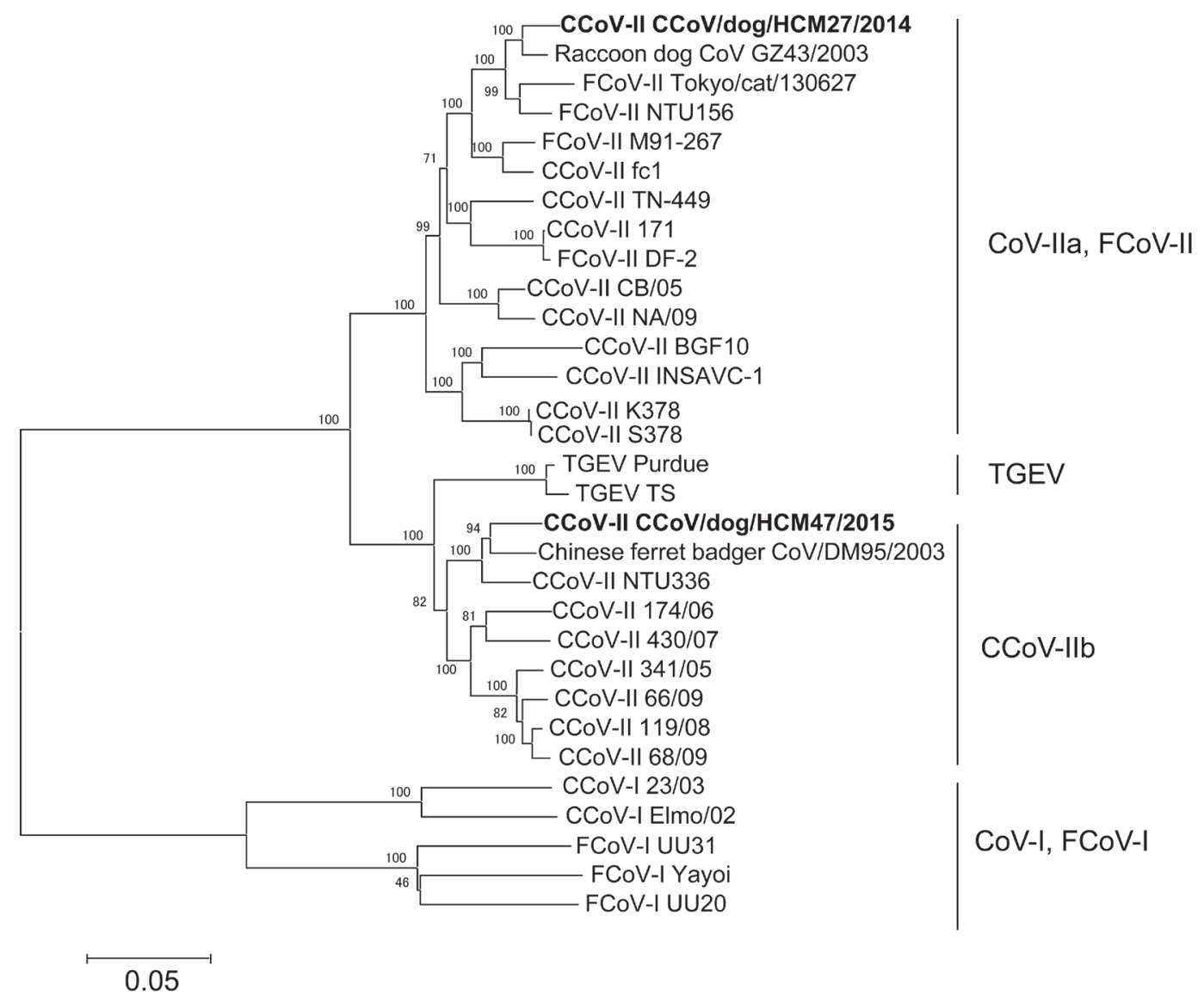

Fig. 2. Phylogenetic analysis based on full length of $\mathrm{S}$ gene of $\mathrm{CCoV}$. Vietnamese isolated and detected $\mathrm{CCoV}$ strains are shown in bold. GeneBank accession numbers of reference strains are as follows: CCoV-II: SK378 (KC175341), K378 (KC175340), Insavc-1 (D13096.1), BGF10 (AY342160.1), NA/09 (JF682842.1), CB/05 (KP981644.1), fc1 (AB781790), TN449 (JQ404410), 171 (KC175339), DM95/2003 (EF192156.1), NTU-336 (GQ477367), 430/07 (EU924790), 174/06 (EU856362), 341/05 (EU856361.1), 66/09 (HQ450376), 68/09 (HQ450377.1), 119/08 (EU924791.1) and Raccoon dog CoV/GZ43/2003 (EF192155). FCoV-I: UU20 (HQ392471.1), UU31 (HQ012371.1) and Yayoi (AB695067.1). FCoV-II: NTU156 (GQ152141.1), DF-2 (DQ286398.1), M91-267 (AB781788.1) and Tokyo/cat/130627 (AB907624.1). CCoV-I: 23/03 (KP84972.1) and Elmo/02 (AY307020.1); TGEV: Purdue (DQ811789.2) and TS (DQ201447).

CCoV-IIa spread systemically and caused hemorrhagic gastroenteritis, neurological signs and leukopenia [8, 16]. CCoV-IIb also spread systemically and infected to internal organs, when it co-infected with canine parvovirus [16, 21]. However, there were no significant differences in $\mathrm{CCoV}$ infection between diarrheic dogs and healthy dogs. CCoV infection may not be a serious problem in Vietnamese dogs. Further studies will be required to clarify the pathogenicity of CCoV in Vietnam.

Phylogenetic and sequence analysis based on S genes showed that Vietnamese CCoV-IIa (CCoV/dog/HCM27/2014) and CCoVIIb (CCoV/dog/HCM47/2015) were smilar to CCoVs in China, Chinese ferret badger CoV/DM95/2003 and raccoon dog CoV/ GZ43/2003, respectively (Fig.2). These Chinese CoVs were found in live animal markets in Shenzhen and Guangzhou, Guangdong Province, China [31], suggesting that Vietnamese CCoVs might have the same ancestor as these Chinese CCoVs. In our previous study, canine distemper virus in Vietnam was also similar to Chinese viruses [20].

We succeeded in isolation of $\mathrm{CCoV} / \mathrm{dog} / \mathrm{HCM} 47 / 2015$ and plague-purified the isolate three times for further characterization. Surprisingly, the plaque-purified CCoV had a large deletion in the ORF3abc and partial E genes $(1,165 \mathrm{nt})$ and a short deletion of ORF7b (60 nt) (Fig. 3). Deletions in ORF3a (47 nt) and ORF3b (31 nt) in CCoV 1-71 [18], a deletion in ORF3b (38 nt) in CB/05 [8] and a deletion in ORF7b (154 nt) in 341/05 [7] have also been reported. These data indicate that ORF3abc and ORF7b are not essential and that they are stable in viral replication in vitro, but not in vivo. In feline CoV, it was reported that ORF3abc plays an important role in the efficient macrophage and monocyte tropism [2] and that deletion of ORF7b is correlated with a loss of virulence [10]. In our preliminary data, two dogs orally inoculated with plaque-purified CCoV/dog/HCM47/2015 did not show any clinical signs, but anti-CCoV antibody increased after challenge. Now, we are examining the virulence of this plaque-purified $\mathrm{CCoV}$. Importantly, virus isolation is important for characterization, but rapid adaptation by passage of coronaviruses should be monitored.

In conclusion, this is the first characterization of $\mathrm{CCoV}$ in Vietnam. In Vietnam, CCoV-IIa and CCoV-IIb, but not CCoV-I, are 


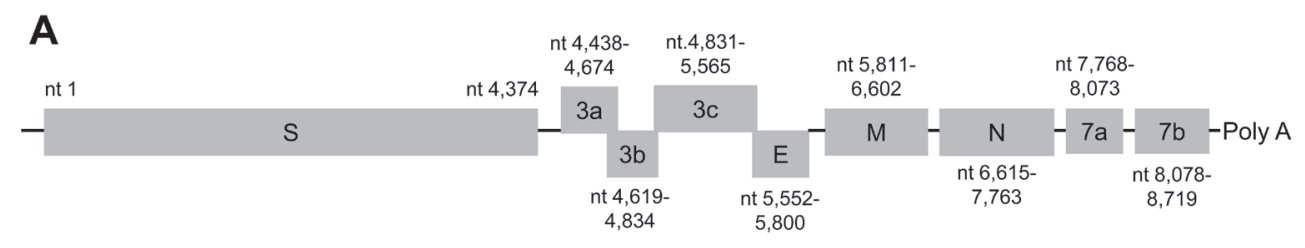

B

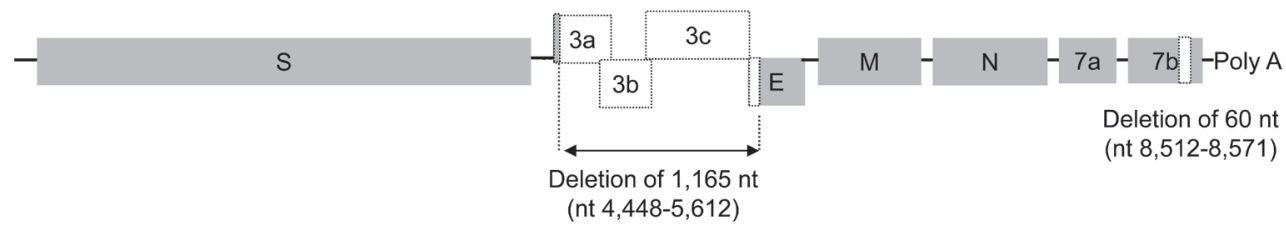

Fig. 3. Schema of $3^{\prime}$-terminal one-third of $\mathrm{CCoV} / \mathrm{dog} / \mathrm{HCM} 47 / 2015$. Nucleotides sequences of $\mathrm{CCoV} /$ $\operatorname{dog} / \mathrm{HCM} 47 / 2015$ in fecal sample (A) and plaque-purified virus (B) were analyzed. Plaque-purified CCoV has a large deletion in ORF3abc and partial E genes (1,165 nt), and a small deletion in the ORF7b gene (60 nt) in comparison with the original $\mathrm{CCoV}$ in fecal samples.

Table 2. Comparison of $\mathrm{VN}$ antibodies against CCoV-IIa fc1 and CCoV-IIb CCoV/dog/ HCM47/2015 among 60 domestic dogs in Ho Chi Minh City, Vietnam

\begin{tabular}{llccc}
\hline & & \multicolumn{2}{c}{ VN test against CCoV/dog/HCM47/2015 } & \multirow{2}{*}{ Total } \\
\cline { 3 - 4 } & & Positive & Negative & \\
\hline \multirow{2}{*}{ VN test against fc1 } & Positive & 31 & 0 & $31(51.7 \%)$ \\
& Negative & 4 & 25 & $29(48.3 \%)$ \\
\hline \multirow{2}{*}{ Total } & & $35(58.3 \%)$ & $25(41.7 \%)$ & $60(100.0 \%)$ \\
\hline
\end{tabular}

co-circulating among domestic dogs. This plaque-purified CCoV/dog/HCM47/2015 may be a good tool for diagnosis of CCoV infection, because of its rapid viral growth in vitro and antigenicity. Furthermore, the virus is a candidate for inactivated and/or attenuated live vaccines, because genetic markers in ORF3abc and $7 \mathrm{~b}$ are able to differentiate it from field isolates.

ACKNOWLEDGMENTS. We would like to thank the veterinarians at animal hospitals for sample collection. This study was funded by the Japan Society for the Promotion and Science (JSPS) KAKENHI (Grant No. 15H04599) and the Japan Agency for Medical Research and Development (AMED). The authors would like to acknowledge the technical expertise of The DNA Core facility of the Center for Gene Research, Yamaguchi University.

\section{REFERENCES}

1. Bandai, C., Ishiguro, S., Masuya, N., Hohdatsu, T. and Mochizuki, M. 1999. Canine coronavirus infections in Japan: virological and epidemiological aspects. J. Vet. Med. Sci. 61: 731-736. [Medline] [CrossRef]

2. Bálint, Á., Farsang, A., Zádori, Z., Hornyák, Á., Dencso, L., Almazán, F., Enjuanes, L. and Belák, S. 2012. Molecular characterization of feline infectious peritonitis virus strain DF-2 and studies of the role of ORF3abc in viral cell tropism. J. Virol. 86: 6258-6267. [Medline] [CrossRef]

3. Benetka, V., Kübber-Heiss, A., Kolodziejek, J., Nowotny, N., Hofmann-Parisot, M. and Möstl, K. 2004. Prevalence of feline coronavirus types I and II in cats with histopathologically verified feline infectious peritonitis. Vet. Microbiol. 99: 31-42. [Medline] [CrossRef]

4. Binn, L. N., Lazar, E. C., Keenan, K. P., Huxsoll, D. L., Marchwicki, R. H. and Strano, A. J. 1974. Recovery and characterization of a coronavirus from military dogs with diarrhea. Proc. Annu. Meet. U. S. Anim. Health Assoc. 78: 359-366. [Medline]

5. Costa, E. M., de Castro, T. X., Bottino, F. O. and Garcia, R. C. 2014. Molecular characterization of canine coronavirus strains circulating in Brazil. Vet. Microbiol. 168: 8-15. [Medline] [CrossRef]

6. Decaro, N. and Buonavoglia, C. 2008. An update on canine coronaviruses: viral evolution and pathobiology. Vet. Microbiol. 132: 221-234. [Medline] [CrossRef]

7. Decaro, N., Mari, V., Elia, G., Addie, D. D., Camero, M., Lucente, M. S., Martella, V. and Buonavoglia, C. 2010. Recombinant canine coronaviruses in dogs, Europe. Emerg. Infect. Dis. 16: 41-47. [Medline] [CrossRef]

8. Decaro, N., Martella, V., Elia, G., Campolo, M., Desario, C., Cirone, F., Tempesta, M. and Buonavoglia, C. 2007. Molecular characterisation of the virulent canine coronavirus $\mathrm{CB} / 05$ strain. Virus Res. 125: 54-60. [Medline] [CrossRef]

9. Gür, S., Ayşe, G. A. and Doğan, N. 2008. A serologic investigation for canine corona virus infection in individually reared dogs in central Anatolia. J. Fac. Vet. Med. Univ. Erciyes. 5: 67-71.

10. Herrewegh, A. A., Vennema, H., Horzinek, M. C., Rottier, P. J. and de Groot, R. J. 1995. The molecular genetics of feline coronaviruses: 
comparative sequence analysis of the ORF7a/7b transcription unit of different biotypes. Virology 212: 622-631. [Medline] [CrossRef]

11. Jacobse-Geels, H. E. and Horzinek, M. C. 1983. Expression of feline infectious peritonitis coronavirus antigens on the surface of feline macrophage-like cells. J. Gen. Virol. 64: 1859-1866. [Medline] [CrossRef]

12. Jeoung, S. Y., Ann, S. Y., Kim, H. T. and Kim, D. 2014. M gene analysis of canine coronavirus strains detected in Korea. J. Vet. Sci. 15: 495-502. [Medline] [CrossRef]

13. Kumar, S., Stecher, G. and Tamura, K. 2016. MEGA7: Molecular evolutionary genetics analysis version 7.0 for bigger datasets. Mol. Biol. Evol. 33: 1870-1874. [Medline] [CrossRef]

14. Le Poder, S. 2011. Feline and canine coronaviruses: common genetic and pathobiological features. Adv. Virol. 2011: 609465. [Medline] [CrossRef]

15. Le Poder, S., Pham-Hung d'Alexandry d'Orangiani, A. L., Duarte, L., Fournier, A., Horhogea, C., Pinhas, C., Vabret, A. and Eloit, M. 2013. Infection of cats with atypical feline coronaviruses harbouring a truncated form of the canine type I non-structural ORF3 gene. Infect. Genet. Evol. 20: 488-494. [Medline] [CrossRef]

16. Licitra, B. N., Duhamel, G. E. and Whittaker, G. R. 2014. Canine enteric coronaviruses: emerging viral pathogens with distinct recombinant spike proteins. Viruses 6: 3363-3376. [Medline] [CrossRef]

17. Licitra, B. N., Whittaker, G. R., Dubovi, E. J. and Duhamel, G. E. 2014. Genotypic characterization of canine coronaviruses associated with fatal canine neonatal enteritis in the United States. J. Clin. Microbiol. 52: 4230-4238. [Medline] [CrossRef]

18. Ma, G., Wang, Y. and Lu, C. 2008. Molecular characterization of the $9.36 \mathrm{~kb}$ C-terminal region of canine coronavirus 1-71 strain. Virus Genes 36: 491-497. [Medline] [CrossRef]

19. Naylor, M. J., Monckton, R. P., Lehrbach, P. R. and Deane, E. M. 2001. Canine coronavirus in Australian dogs. Aust. Vet. J. 79: 116-119. [Medline] [CrossRef]

20. Nguyen, D. V., Suzuki, J., Minami, S., Yonemitsu, K., Nagata, N., Kuwata, R., Shimoda, H., Vu, C. K., Truong, T. Q. and Maeda, K. 2017. Isolation and phylogenetic analysis of canine distemper virus among domestic dogs in Vietnam. J. Vet. Med. Sci. 79: 123-127.

21. Ntafis, V., Mari, V., Decaro, N., Papanastassopoulou, M., Papaioannou, N., Mpatziou, R., Buonavoglia, C. and Xylouri, E. 2011. Isolation, tissue distribution and molecular characterization of two recombinant canine coronavirus strains. Vet. Microbiol. 151: 238-244. [Medline] [CrossRef]

22. Pratelli, A. 2006. Genetic evolution of canine coronavirus and recent advances in prophylaxis. Vet. Res. 37: 191-200. [Medline] [CrossRef]

23. Pratelli, A. 2011. The evolutionary processes of canine coronaviruses. Adv. Virol. 2011: 562831. [Medline] [CrossRef]

24. Pratelli, A., Elia, G., Martella, V., Palmieri, A., Cirone, F., Tinelli, A., Corrente, M. and Buonavoglia, C. 2002. Prevalence of canine coronavirus antibodies by an enzyme-linked immunosorbent assay in dogs in the south of Italy. J. Virol. Methods 102: 67-71. [Medline] [CrossRef]

25. Sakulwira, K., Vanapongtipagorn, P., Theamboonlers, A., Oraveerakul, K. and Poovorawan, Y. 2003. Prevalence of canine coronavirus and parvovirus infections in dogs with gastroenteritis in Thailand. Vet. Med. 48: 163-167.

26. Shiba, N., Maeda, K., Kato, H., Mochizuki, M. and Iwata, H. 2007. Differentiation of feline coronavirus type I and II infections by virus neutralization test. Vet. Microbiol. 124: 348-352. [Medline] [CrossRef]

27. Soma, T., Ohinata, T., Aoki, E. and Kurita, K. 2012. Prevalence of canine coronvairus amd canine parvovirus type 2 infections in pet shop in Japan. J. Anim. Clin. Med 21: 126-129.

28. Soma, T., Ohinata, T., Ishii, H., Takahashi, T., Taharaguchi, S. and Hara, M. 2011. Detection and genotyping of canine coronavirus RNA in diarrheic dogs in Japan. Res. Vet. Sci. 90: 205-207. [Medline] [CrossRef]

29. Takano, T., Yamashita, S., Murata-Ohkubo, M., Satoh, K., Doki, T. and Hohdatsu, T. 2016. Prevalence of canine coronavirus (CCoV) in dog in Japan: detection of CCoV RNA and retrospective serological analysis. J. Vet. Med. Sci. 78: 341-345. [Medline] [CrossRef]

30. Terada, Y., Matsui, N., Noguchi, K., Kuwata, R., Shimoda, H., Soma, T., Mochizuki, M. and Maeda, K. 2014. Emergence of pathogenic coronaviruses in cats by homologous recombination between feline and canine coronaviruses. PLOS ONE 9: e106534. [Medline] [CrossRef]

31. Vijaykrishna, D., Smith, G. J. D., Zhang, J. X., Peiris, J. S. M., Chen, H. and Guan, Y. 2007. Evolutionary insights into the ecology of coronaviruses. J. Virol. 81: 4012-4020. [Medline] [CrossRef]

32. Wang, X., Li, C., Guo, D., Wang, X., Wei, S., Geng, Y., Wang, E., Wang, Z., Zhao, X., Su, M., Liu, Q., Zhang, S., Feng, L. and Sun, D. 2016. Co-circulation of canine coronavirus I and IIa/b with high prevalence and genetic diversity in Heilongjiang province, northeast China. PLOS ONE 11: e0146975. [Medline] [CrossRef] 